\title{
Long term changes in abundance of Coccinella septempunctata (Coleoptera: Coccinellidae) in the Czech Republic
}

\author{
AlOIS HONĚK and ZDEŇKA MARTINKOVÁ \\ Research Institute of Crop Production, Drnovská 507, CZ 16106 Praha 6 - Ruzyně, Czech Republic; e-mail: honek@vurv.cz
}

Key words. Coccinellidae, hibernation, abundance, population change, agriculture practices, fertilization, land use, cereal aphids, Coccinella septempunctata, Metopolophium dirhodum, Sitobion avenae, Rhopalosiphum padi

\begin{abstract}
Since 1978, the abundance of Coccinella septempunctata L. has been recorded at a hibernation site in the western Czech Republic. Over the years, abundance varied by two orders of magnitude and a long-term trend for decrease in C. septempunctata abundance was observed beginning in the early 1990s. This recession was correlated with the decreasing abundance of its dominant prey, cereal aphids. The acreage of small grain cereals and other crops suitable for breeding C. septempunctata populations also decreased. The change in abundance of cereal aphids may be associated with a dramatic decrease in fertilizer input after 1990. Decreasing fertilizer use has changed the quality of small grain cereal crops and is reflected in lower yields.
\end{abstract}

\section{INTRODUCTION}

In Central Europe, Coccinella septempunctata L. is the dominant species in coccinellid communities preying on aphids of agricultural crops (Hodek et al., 1966; Honěk \& Rejmánek, 1982). Because it is also common on wild herbaceous plants, shrubs and trees, C. septempunctata is probably the most abundant coccinellid species in the region. According to our observations in the western Czech Republic (A. Honěk, unpubl.) abundance of this species has decreased over the past 10 years. In this paper we document this change and propose an explanatory hypothesis.

To understand the proposed mechanism of change we should consider the factors determining C. septempunctata abundance (Honěk, 1982, 1989). In most years, $C$. septempunctata has only one generation. In May-July, the larvae feed on aphids infesting crops and wild plants. Important crops are small grain cereals populated by Metopolophium dirhodum (Walker), Rhopalosiphum padi (Linné) and Sitobion avenae (Fabricius). Since their acreage is large, a significant proportion of the total $C$. septempunctata population develops in cereal stands. Consequently the size of the C. septempunctata population entering hibernacula (in late summer) is correlated with abundance of cereal aphids. Aphid numbers are determined by several factors including the cultural practices used in cereal production. By influencing abundance of cereal aphids agricultural practices consequently also affect $C$. septempunctata abundance.

We propose a hypothesis that explains the decline in $C$. septempunctata abundance as the result of changes associated with the economic transformation of the country that occurred in the 1990s. Until 1989, agricultural production in Czechoslovakia was strongly subsidized (Anonymous, 1981). This subsidy largely ceased after 1990 and the change affected both land use and agricultural practices. Areas sown to small grain cereals and other crops favourable for conservation and breeding of
C. septempunctata populations decreased while areas of unfavorable crops increased. Overall, the intensity of agricultural production decreased. This change brought a dramatic decrease in fertilizer doses applied annually to different crops. Consequently, the quality of small grain cereals as aphid hosts decreased and lower aphid abundances negatively influenced $C$. septempunctata populations. Thus, both changes in land use and agricultural practices became less favourable for $C$. septempunctata and may have contributed to the long-term decline in its abundance.

In this paper we test this hypothesis using three sets of data. We provide (i) a 26 year record of $C$. septempunctata abundance, (ii) a 16 year record of cereal aphid abundance, and (iii) economic statistics showing changing trends in land use and agricultural practices that may have affected C. septempunctata abundance.

\section{MATERIAL AND METHODS}

\section{Abundance of $C$. septempunctata}

Overwintering C. septempunctata adults were counted at a hibernation site at Raná in the western Czech Republic $\left(50^{\circ} 24^{\prime} 14^{\prime \prime} \mathrm{N}, 13^{\circ} 46^{\prime} 16^{\prime \prime} \mathrm{E}\right.$, altitude $390 \mathrm{~m}$ a.s.l.). This hibernation site is a large grassy area several hundred meters square situated on a southwestern slope below the western top of the Raná hill. The steppe character of the location is naturally maintained. Plant succession is prevented by a very dry shallow (2-3 $\mathrm{cm})$ soil stratum covering volcanic bedrock, fully exposed to sun and wind. Thus, the quality of the hibernation site has remained the same since the start of the work in the 1970s. The plant cover consists of individual grass tussocks separated by 5-20 cm wide spaces of bare ground. Adults of C. septempunctata overwinter within these grass tussocks between the densely packed stalks, sitting as deeply as possible. In years of very high coccinellid abundance a portion of the adults may overwinter outside the tussocks, below the grass plume bent to the ground by the prevailing western winds. Coccinellids were counted every year between 1978-2004, using the same method. Counts were made on a single day between September 20 - October 20, at a time when immigration to the overwintering site was com- 
plete (Honěk, 1989) but winter mortality still at a minimum. The tussocks were carefully spread apart and the individuals inside were counted. On each occasion, coccinellids were counted at 3 $\times 100$ to $9 \times 100$ (usually $5 \times 100$ ) tussocks. The average number of coccinellids per tussock was calculated for each hundred tussocks as (number of established adults +1 ) $* 100^{-1}$. Average number of coccinellids for a year was calculated as an arithmetic mean $( \pm \mathrm{SE})$ of mean numbers per each hundred tussocks. The abundances of adults aggregated in hibernacula are correlated with their abundances in cereal stands in the next spring (Honěk, 1989). Therefore the abundance established in a year stood for abundance of "parent population" for the next year.

\section{Abundance of cereal aphids}

Cereal aphids, M. dirhodum, S. avenae and $R$. padi, were counted in stands of winter wheat grown at Praha - Ruzyně $\left(50^{\circ} 06^{\prime} \mathrm{N}, 14^{\circ} 16^{\prime} \mathrm{E}\right.$, altitude $340 \mathrm{~m}$ a.s.1.). The method of aphid counting was standardized in 1987 (Honěk, 1991a; Honěk \& Martinková, 1999). Each year, aphids were counted on 3-6 sites established within production stands of winter wheat where the quality of plants was similar to ordinary production stands in the area. At each site, the aphids were censused in weekly intervals, starting from immigration (usually mid-May) until their disappearance (mid-July). On each occasion, aphids were counted on 30-300 tillers, according to their abundance, and mean aphid numbers per tiller calculated. Numbers of all aphid species were counted together because $C$. septempunctata adults and larvae search the whole plant and make no distinction between aphid species. The weekly counts enabled us to establish the maximum aphid numbers per tiller occurring in a given year. The maximum number for a particular year was calculated as the arithmetic mean $( \pm$ SE) of maximum numbers counted at particular sites.

\section{Land use, fertilizer doses and yields}

These data were retrieved from official statistics published every year in the Statistical Yearbooks (Anonymous 1972-1989, 1990-1992, 1993-2003). To describe the trends in land use, fertilizer doses and yields we used average data for the Czech Republic, because the structure of published data and division of the territory into districts changed over the years.

\section{Data processing}

The relationship between variables was approximated by simple linear $\left(\mathrm{y}=\mathrm{a}_{0}+\mathrm{a}_{1} \mathrm{x}\right)$ or multiple linear $\left(\mathrm{z}=\mathrm{a}_{0}+\mathrm{a}_{1} \mathrm{x}+\mathrm{a}_{2} \mathrm{y}\right)$ regressions. The regression and correlation (R) was calculated using Statistica for Windows (StatSoft, 1994).

\section{RESULTS}

\section{Abundance of $C$. septempunctata}

The abundance of $C$. septempunctata at the hibernation site at Raná since 1978 revealed a decreasing trend (Fig. 1). Before 1990, abundance of C. septempunctata in different years varied around the average value $0.98 \pm 0.21$ individuals per tussock, by ca. 1 order magnitude. There were only two years $(1987,1988)$ when abundance was $<0.1$ individuals per tussock. The average abundance began to decrease after 1990, although in some years (1992, 1996) it was also high, $>1.0$ individuals per tussock. However, the trend for decrease in C. septempunctata numbers was remarkable. After 1993, in nine years out of 11 the abundance was $<0.1$ individuals per tussock (average $0.17 \pm 0.10$ individuals per tussock). This decline in abundance was significant for the whole series
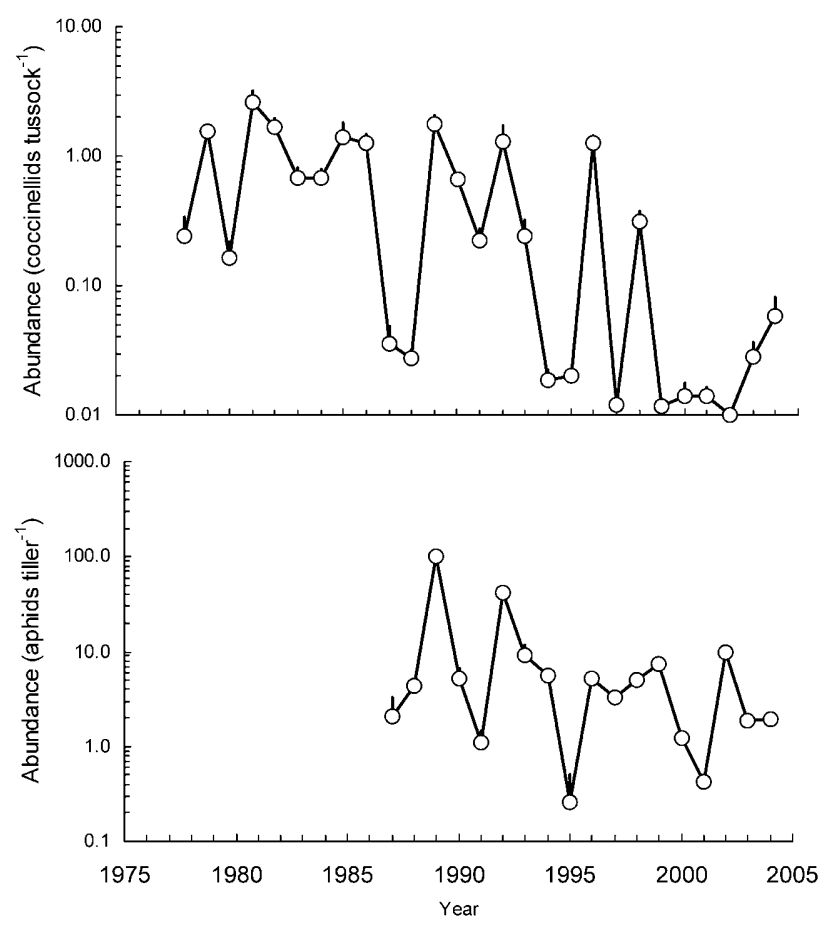

Fig. 1. Long-term change in C. septempunctata and cereal aphid abundances. Above: The average abundance (+SE) of $C$. septempunctata adults at the overwintering site at Raná, in 1978-2004. Below: The average maximum abundance (+SE) of cereal aphids, in 1987-2004. Data for aphid numbers on leaves and ears, and for all aphid species (M. dirhodum, R. padi, S. avenae) combined.

of the data taken together $\left(\mathrm{a}_{0}=0.212, \mathrm{a}_{1}=-0.071, \mathrm{df}=\right.$ $25, \mathrm{R}=0.657, \mathrm{p}<0.001)$.

\section{Abundance of cereal aphids}

Between 1987-2004, the maximum abundance of cereal aphids varied by ca. 3 orders of magnitude (Fig. 1). The average abundance before 1995 (21.5 \pm 11.7 aphids tiller-1) was significantly higher than in the years thereafter (3.6 \pm 1.0 aphids per tiller). The abundance of $C$. septempunctata in a particular year also depends on the abundance of the parental generation surviving from the previous year. We investigated the combined effect of both aphid abundance in the current year and size of parental C. septempunctata population surviving from the previous year. Multiple regression of C. septempunctata abundance on aphid density and abundance of its parental generation (Fig. 2) was highly significant $\left(\mathrm{a}_{0}=0.102, \mathrm{a}_{1}=\right.$ $\left.0.018, \mathrm{a}_{2}=0.060, \mathrm{R}=0.800, \mathrm{~F}_{2,15}=13.35, \mathrm{p}<0.001\right)$. While aphid abundance contributed significantly to this relationship $\left(\mathrm{t}_{15}=5.15, \mathrm{p}<0.001\right)$ the contribution of parental abundance was not significant $\left(\mathrm{t}_{15}=0.41, \mathrm{p}>\right.$ $0.05)$. This was because, in the period of observation, the parental generation was abundant only in years when aphids were scarce and aphids were abundant only in years when the parental generation was scarce.

\section{Changes in agriculture}

In consequence of economic transformation land use changed dramatically after 1989 (Table 1). The area cov- 


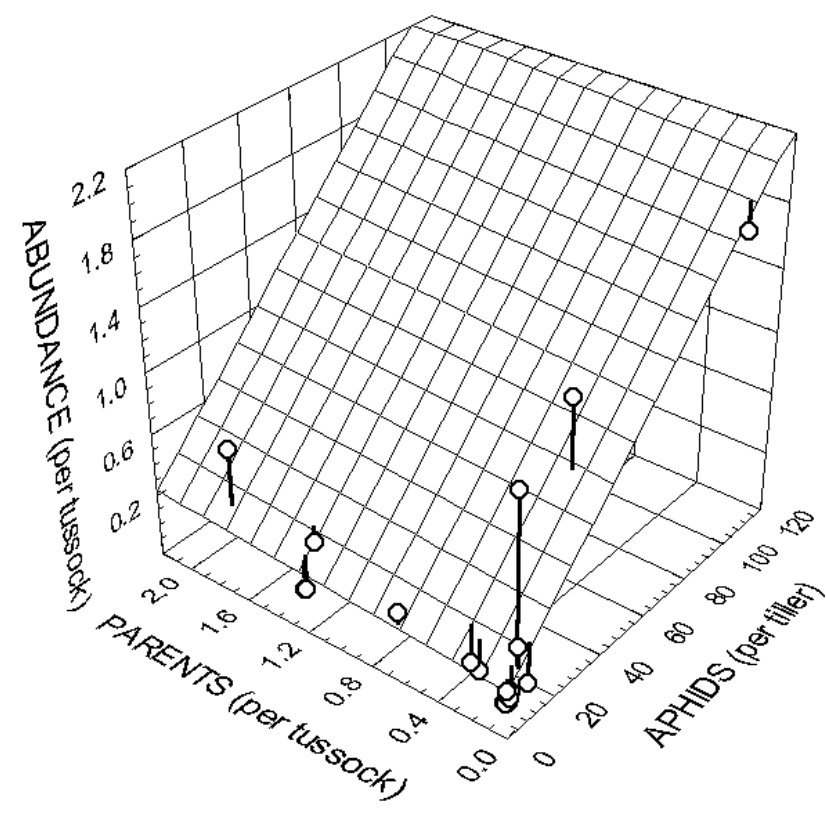

Fig. 2. The relationship between cereal aphid abundance (individuals per tiller) in a particular year (APHIDS), abundance of $C$. septempunctata population (individuals per tussock) overwintered from the previous year (PARENTS) and abundance of C. septempunctata population (individuals per tussock) produced in a given year (ABUNDANCE). Data of 1987-2004.

ered by crops that are important for the reproduction of $C$. septempunctata populations mostly decreased. The area planted to small grain cereals decreased by c. $200 \mathrm{~km}^{2}$ (12\%) compared to the maximum area before 1990. Areas of other favourable crops also decreased - maize (31\%), alfalfa and clover (56\%) and annual fodder crop mixtures of cereals and leguminosae (68\%). Crops that occasionally host abundant $C$. septempunctata populations, but are frequently treated chemically (and therefore are less suitable as host crops), also dramatically decreased - sugar beet $(50 \%)$ and potatoes $(64 \%)$. The decrease in area planted to favourable crops was compensated by a 4.1

TABLE 1. Land use in the Czech Republic. Average areas calculated over five year periods $\left(\mathrm{km}^{2}\right)$ of arable land, grasslands and crops favourable and unfavourable for development of $C$. septempunctata populations.

\begin{tabular}{lccccc}
\hline & \multicolumn{5}{c}{ Year } \\
\cline { 2 - 6 } & $1981-85$ & $1986-90$ & $1991-95$ & $1996-00$ & $2001-02$ \\
\hline Arable land & 32832 & 32412 & 31720 & 30936 & 30715 \\
Grasslands and pastures & 8380 & 8286 & 8794 & 9514 & 9670 \\
\hline$\quad$ Favourable crops & & & & & \\
Small grain cereals & 16756 & 16124 & 15516 & 15772 & 14740 \\
Maize & 3418 & 4098 & 3372 & 2928 & 2845 \\
Alfalfa and clover & 3378 & 3656 & 3006 & 2000 & 1625 \\
Annual fodder crops & 1920 & 1888 & 1414 & 938 & 605 \\
Potatoes & 1308 & 1186 & 968 & 748 & 465 \\
Sugar and forage beet & 1620 & 1422 & 1186 & 906 & 810 \\
\hline$\quad$ Unfavourable crops & & & & & \\
Rape & 808 & 996 & 1748 & 2800 & 3285 \\
\hline
\end{tabular}
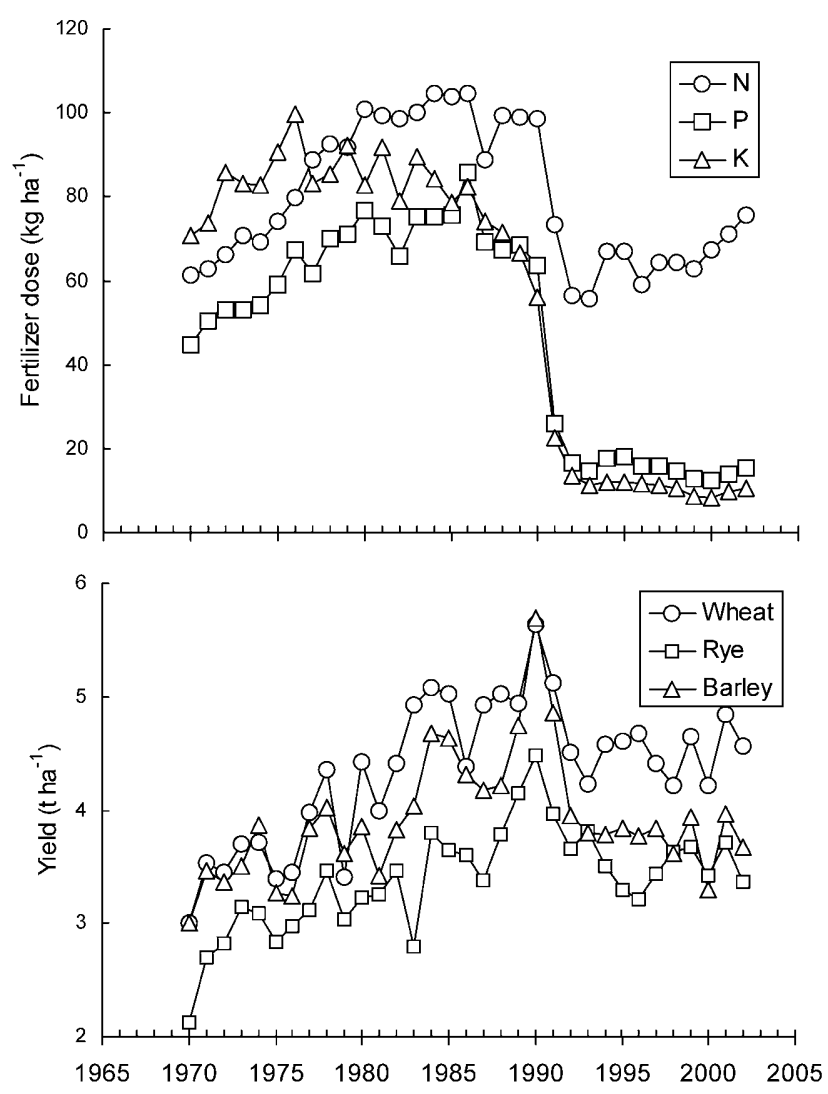

Fig. 3. Fertilizer doses and small grain cereals yields in 1970-2002. Above: Average doses $\left(\mathrm{kg} \mathrm{ha}^{-1}\right)$ of pure elements, nitrogen $(\mathrm{N})$, phosphorus $(\mathrm{P})$ and potassium $(\mathrm{K})$, applied to crops on arable land in the Czech Socialist Republic (1970-1989) and the Czech Republic (1990-2002). Below: Average yields $\left(\mathrm{t} \mathrm{ha}^{-1}\right)$ of principal small grain cereals in the same country.

times increase in the plantings of oilseed rape since the late 1970 s. At the same time the area covered by grasslands and pastures increased (15\%) and arable land decreased by c. $2,000 \mathrm{~km}^{2}$.

Average fertilizer doses applied to crops also changed dramatically during this time frame (Fig. 3). The doses increased steadily before 1990, then decreased abruptly. Thus in 1991-2004, average applications of nitrogen decreased by $34 \%$ compared to applications in 1981-1990. Still more important was the decrease in phosphorus $(78 \%)$ and potassium $(85 \%)$ applications.

Collectively, these changes all affected the quality of small grain cereal stands and became manifest in lower yields (Fig. 3). Although the decrease after 1990 was gradual, average yields of small grain cereals in 1996-2002 were lower than in 1986-1990, by $10 \%$ (wheat and rye) to $19 \%$ (barley).

\section{DISCUSSION}

\section{Short- and long-time population trends in coccinellid populations}

Annual fluctuations in abundance have been revealed by studies of coccinellid species using time series data collected from light traps (Honěk \& Kocourek, 1986), 
counting at at hibernation sites (Lipa et al., 1975) and sampling in field crop stands. Thus, in a thirteen year (1973-1985) study in alfalfa stands (Elliott \& Kieckhefer, 1990) and maize stands (Kieckhefer \& Elliott, 1990) fluctuations in numbers of several coccinellid species were observed to vary by ca. one order of magnitude. In these studies, the fluctuation in numbers was irregular, without a particular long-term trend. Large variations in coccinellid numbers have been recorded occasionally, and may became manifest by conspicuous assemblages on water shores (Klausnitzer, 1989; Majerus \& Majerus, 1996; Nalepa et al., 1998). In an unpublished study using 11 year series of data from a light trap at Praha - Ruzyně, A. Mackenzie, J.I. Thacker and A.F.G. Dixon established direct density dependence for population fluctuations in 5 out of 13 coccinellid species, and none of these species showed delayed density dependence.

Unlike annual fluctuations, long-time trends in abundance of coccinellid species have been little studied. This is not only because of the absence of long data series, but also because of a paucity of environmental changes that may elicit long term changes in coccinellid population densities. In the 1980s, G. Iperti (oral communication in the Fifth Symposium Ecology of Aphidophaga, Colle-surLoup near Antibes, France, 1993) established gradual decrease of Ceratomegilla (Semiadalia) undecimnotata (Schneider) abundance in overwintering sites at southern France. In this case, coccinellid decline followed a change in land use (increasing area of maize) in this area. Recent studies in North America have revealed different factors influencing abundance change. Abundance of several native North American coccinellid species decreased following the introduction of two large Eurasian species, C. septempunctata and Harmonia axyridis (Pallas). A 20 year study on maize, small grain and alfalfa fields in central USA revealed a significant decrease (by 95-97\%) in abundance of native species after arrival of C. septempunctata (Elliott et al., 1996). In another 6 year study of apple orchards in the eastern USA, C. septempunctata had been dominating species but was suddenly replaced by $H$. axyridis (Brown \& Miller, 1998). Similar long-time changes in abundance of native species and introduced species were observed in southern Canada (Turnock et al., 2003).

\section{Relevance of experimental data}

Before discussing our results we should consider whether data of only two localities situated c. $50 \mathrm{~km}$ one from the other are relevant for establishing general trends shown by $C$. septempunctata and cereal aphid populations. The hibernation site at Raná was selected because of its stable character and lowland, but prominent, position. Other lowland hibernation sites investigated in our earlier study (Honěk, 1989) became shaded because of the growth of surrounding vegetation and thus unsuitable for coccinellid overwintering. Its prominent position at the top of a solitary volcanic hill and its low relative altitude (c. 100-150 m above surrounding fields) makes the Raná hibernation site easily accessible and thus attractive to coccinellids from a wide surrounding area. This is demonstrated by the occurrence of several other coccinellid species, Hippodamia (Adonia) variegata (Goeze), Coccinella quinquepunctata Linné and Semiadalia undecimnotata in C. septempunctata hibernaculum (Hodek, 1960). Thus the hibernaculum may be available to many individuals although $C$. septempunctata is not a strong migrant and limits its flight activity to the surface layer (Boiteau et al., 1999). The population of the Raná hibernation site is thus a naturally selected "average" from populations of surrounding fields where abundances vary between crops. By contrast, other "stable" hibernacula are "mountain" sites situated at $>700$ m elevation (Honěk, 1989). The long distance to be flown from lowland fields to a mountain hibernaculum (sometimes $>15 \mathrm{~km}$ and $1000 \mathrm{~m}$ elevation difference) prevents "weak" individuals from using these overwintering sites. Mountain hibernacula are thus preferentially used by large individuals (Honěk, 1989; Nalepa et al., 1996; Ceryngier, 2000) and the migration can be negatively influenced by unfavourable weather (Sárospataki \& Markó, 1995). However, in 2002-2004 we established $C$. septempunctata abundance at several high altitude hibernacula investigated in the previous study (Honěk, 1989). This survey (Honěk \& Martinková, unpubl.) indicated a trend of decreasing $C$. septempunctata abundance parallel to that found at the lowland Raná hibernation site.

Measurement of cereal aphid population density also involves generalizing the data from one locality to the whole region. Making this generalization was inevitable because of difficulties with determining maximum aphid abundances. In the spring, aphid population densities increase rapidly and population peaks persist for only few days. Thus one week intervals between aphid censuses are the maximum that can be tolerated for precise estimation of aphid peaks. It was impracticable for the authors to make censuses at several remote localities and no data of this kind collected by other authors are available. Our earlier investigation indicated a correlated variation in abundance of cereal aphids at several remote localities (Honěk, 1985a). Therefore we used the data of Ruzyně as a surrogate for average cereal aphid abundance in the region and supposed that its spatial variation within a year was small compared to the large between-year differences. There is some additional evidence that cereal aphid abundances decreased after 1990, namely the decreasing number of economic aphid infestations reported by farmers (J. Madar, pers. commun.). Also, flight activity of $S$. avenae and $M$. dirhodum established in five suction traps situated in different parts of the Czech Republic remained low in 1994-2002 and only increased in 2003 (Lukášová, 2003). Unfortunately there are no data from suction traps before 1993.

\section{Causes of population trends}

Accepting the reality of the observed changes in C. septempunctata and cereal aphid abundance we may discuss details of our explanatory hypothesis. The hypothesis supposes two factors of change in C. septempunctata abundance, (i) decreasing quality of the main crop providing species' prey (cereals) and (ii) decreasing area of 
crops favourable for species' breeding. Our earlier work (Honěk, 1982, 1989) indicated that cereals are the main crop for breeding C. septempunctata populations because of large acreage, frequently high aphid abundance, convenient microclimate, absence of insecticide treatments and late harvest date. This suitability is responsible for the correlation between $C$. septempunctata abundance in cereal stands and that observed in overwintering sites (Honěk, 1989). A decreasing abundance of aphids in cereal stands may thus affect overall C. septempunctata abundance. Our hypothesis first supposes the effect of decreasing fertilization. Since high fertilizer doses are generally favourable for cereal aphids (Honěk, 1991b; Duffield et al., 1997), the dramatic decrease in fertilizer doses after 1990 could have negatively affected aphid populations. In fact, cereal yields did not decrease as dramatically as fertilization. This was probably because (i) growing cereals continued only in favourable areas and (ii) the use of efficient cultivars compensated for decreased fertilization and (iii) residual $\mathrm{N}$ that persisted in the soil from years of over-fertilization. Effect of fertilizers also might be compensated by increased activity of soil decomposers that favour cereal plant vigour and aphid performance (Bonkowski et al., 2001). Even so, we suppose that low fertilizer doses were an important factor influencing cereal aphid abundance, although other factors may have contributed.

Land use also underwent dramatic changes and the areas of all crops favourable for $C$. septempunctata breeding decreased. These crops include forage leguminosae (e.g. alfalfa and clover) that usually host abundant coccinellid populations. At present, C. septempunctata may be more successful in these stands because the destructive harvest methods that formerly killed a large proportion of the overwintered populations (Honěk, 1982) have been replaced by more conservative ones. The increase in areas planted to winter rape may negatively influence $C$. septempunctata populations. In the Czech Republic rape stands are occasionally populated by Brevicoryne brassicae L. which is avoided by C. septempunctata (for older data se Hodek 1973, 1996; Khan \& Khan, 2002; Omkar et al., 2002) and an unsuitable food for other coccinellids (Francis et al., 2001). Although $C$. septempunctata live in rape stands (Honěk, 1985b) these populations cannot compensate for the deficits caused by rare occurrence of aphid populations in cereal stands. We thus believe that our hypothesis explaining the decrease of $C$. septempunctata abundance by change in land use and agriculture practices is essentially correct. This opinion has now been corroborated by models of the abundance of $C$. septempunctata populations following changes in these parameters (Bianchi, Honěk \& van der Werf, in prep).

ACKNOWLEDGEMENTS. We thank H. Uhlírová for excellent technical assistance. The project was supported by grant 522/05/0765 of the Grant Agency of the Czech Republic and grants no. 00027006-01 (to Z.M.) and 00027006-03 (to A.H.) of the Ministry of Agriculture of the Czech Republic.

\section{REFERENCES}

Anonymous 1972-1989: Statistical Yearbook of the Czechoslovak Socialist Republic. SNTL-Alfa, Praha-Bratislava (in Czech).

Anonymous 1981: Sixteenth Congress of the Communist Party of Czechoslovakia. Svoboda, Praha, 285 pp. (in Czech).

Anonymous 1990-1992: Statistical Yearbook of the Czech and Slovak Federative Republic. SNTL, Praha. (in Czech).

Anonymous 1993-2003: Statistical Yearbook of the Czech Republic. Český statistický úřad, Praha.

Boiteau G., Bousquet Y. \& Osborn W.P.L. 1999: Vertical and temporal distribution of Coccinellidae (Coleoptera) in flight over an agricultural landscape. Can. Entomol. 131: 269-277.

Bonkowski M., Geoghegan I.E., Birch A.N. \& Griffiths B.S. 2001: Effects of soil decomposer invertebrates (protozoa and earthworms) on an above-ground phytophagous insect (cereal aphid) mediated through changes in the host plant. Oikos 95 : 441-450.

Brown M.W. \& Miller S.S. 1998: Coccinellidae (Coleoptera) in apple orchards of eastern West Virginia and the impact of invasion by Harmonia axyridis. Entomol. News 109: 143-151.

Ceryngier P. 2000: Overwintering of Coccinella septempunctata (Coleoptera: Coccinellidae) at different altitudes in the Karkonosze Mts, SW Poland. Eur. J. Entomol. 97: 323-328.

Duffield S.J., Bryson R.J., Young J.E.B., Sylvester-Bradley R. \& Sсотт R.K. 1997: The influence of nitrogen fertiliser on the population development of the cereal aphids Sitobion avenae (F.) and Metopolophium dirhodum (Wlk.) on field grown winter wheat. Ann. Appl. Biol. 30: 13-26.

ElLIOTt N.C. \& KieCKHEFer R.W. 1990: A thirteen-year survey of the aphidophagous insects of alfalfa. Prairie Nat. 22: $87-96$.

Elliott N.C., Kieckhefer R.W. \& Kauffman W. 1996: Effects of an invading coccinellid on native coccinellids in an agricultural landscape. Oecologia 105: 537-544.

Francis F., Lognay G., Wathelet J.P. \& Haubruge E. 2001: Effects of allelochemicals from first (Brassicaceae) and second (Myzus persicae and Brevicoryne brassicae) trophic levels on Adalia bipunctata. J. Chem. Ecol. 27: 243-256.

Hodek I. 1960: Hibernation-bionomics in Coccinellidae. Čas. Čs. Spol. Entomol. 57: 1-20.

Hodek I. 1973: Biology of Coccinellidae. Academia, Praha \& Dr. W. Junk, The Hague, 260 pp.

Hodek I. 1996: Food relationships. In Hodek I. \& Honěk A. (eds): Ecology of Coccinellidae. Kluwer Academic Publishers, Dordrecht, pp 143-238.

Hodek I., Holman J., Starý P., Štys P. \& Zelený J. 1966: Natural Enemies of Aphis fabae in the CSSR. Academia, Praha, $126 \mathrm{pp}$.

HoNĚK A. 1982: The distribution of overwintered Coccinella septempunctata L. (Col., Coccinellidae) adults in agricultural crops. Z. Angew. Entomol. 94: 311-319.

HoNĚK A. 1985a: Temperature and plant vigour influence annual variation of abundance in cereal aphids (Homoptera, Aphididae). Z. Pflkrankh. Pflschutz 92: 588-593.

HoNĚK A. 1985b: Habitat preferences of aphidophagous coccinellids (Coleoptera). Entomophaga 30: 253-264.

HoNĚK A. 1989: Overwintering and annual changes of abundance of Coccinella septempunctata in Czechoslovakia (Coleoptera, Coccinellidae). Acta Entomol. Bohemoslov. 86: 179-192.

HoNĚK A. 1991a: Factors determining the peak abundance of Metopolophium dirhodum (Homoptera, Aphididae) on cereals. Bul. Entomol. Res. 81: 57-64. 
HoNĚK A. 1991b: Nitrogen fertilization and abundance of the cereal aphids Metopolophium dirhodum and Sitobion avenae (Homoptera, Aphididae). Z. Pflkrankh. Pflschutz 98: 655-660.

HonĚK A. \& Kocourek F. 1986: The flight of aphid predators to a light trap: possible interpretations. In Hodek I. (ed.): Ecology of Aphidophaga. Academia, Praha \& Dr. W. Junk, Dordrecht, pp. 333-338.

HonĚK A. \& MARTINKovÁ Z. 1999: Host-plant mediated influences on population development of Sitobion avenae (Sternorrhyncha: Aphididae). Eur. J. Entomol. 96: 135-141.

HoNĚK A. \& REJMÁNEK M. 1982: The communities of adult aphidophagous Coccinellidae (Coleoptera): a multivariate analysis. Acta Oecol. Oecol. Appl. 3: 95-104.

KHAN M.R. \& KHAN M.R. 2002: Prey preference and prey switching behaviour of Coccinella septempunctata L. (Coleoptera: Coccinellidae). Internat. J. Agric. Biol. 4: 110-112.

KiecKhefer R.W. \& ElliotT N.C. 1990: A 13-year survey of the aphidophagous Coccinellidae in maize fields in eastern South Dakota. Can. Entomol. 122: 579-581.

KlausnitZer B. 1989: Marienkäferansammlungen am Ostseestrand. Entomol. Nachr. Berlin 33: 189-194.

Lipa J.J., Pruszynski S. \& Bartkowski J. 1975: The parasites and survival of the lady bird beetles (Coccinellidae) during winter. Acta Parasitol. Pol. 23: 453-461.

LuKÁšová H. 2003: Aphid monitoring system in the Czech Republic. In Labanowski G. (ed.): Aphids and Other Hemip- terous Insects 9. Instytut Sadownictwa i Kwiaciarstva, Skierniewice, pp. 93-102.

MaJerus M.E.N. \& MaJerus T.M.O. 1996: Ladybird population explosions. Br. J. Entomol. Nat. Hist. 9: 65-76.

Nalepa C.A., Kidd K.A. \& Ahlstrom K.R. 1996: Biology of Harmonia axyridis (Coleoptera: Coccinellidae) in winter aggregations. Ann. Entomol. Soc. Am. 89: 681-685.

Nalepa C.A., Ahlstrom K.R., Nault B.A. \& Williams J.L. 1998: Mass appearance of lady beetles (Coleoptera: Coccinellidae) on North Carolina beaches. Entomol. News 109: 277-281.

Omkar, Srivastava S. \& James B.E. 2002: Prey preference of a lady beetle, Coccinella septempunctata Linnaeus (Coleoptera: Coccinellidae). J. Adv. Zool. 18: 96-97.

SÁrospataki M. \& MARKó V. 1995: Flight activity of Coccinella septempunctata (Coleoptera: Coccinellidae) at different strata of a forest in relation to migration to hibernation sites. Eur. J. Entomol. 92: 415-419.

StatSoft 1994: Statistica. Volume I. General Conventions and Statistics I. StatSoft Technical Support, Tulsa, Oklahoma, $1718 \mathrm{pp}$.

Turnock W.J., Wise I.L. \& Matheson F.O. 2003: Abundance of some native coccinellines (Coleoptera: Coccinellidae) before and after the appearance of Coccinella septempunctata. Can. Entomol. 135: 391-404.

Received October 29, 2004; revised and accepted April 30, 2005 